\title{
High-Resolution Melting Curve Analysis to Predict Extended Blood Group Phenotypes among Thai Donors and Patients
}

\author{
Oytip Nathalang $^{\mathrm{a}}$ Kamphon Intharanut $^{\mathrm{a}}$ Sarisa Chidtrakoon ${ }^{\mathrm{b}}$ \\ ${ }^{\mathrm{a}}$ Graduate Program in Biomedical Sciences, Faculty of Allied Health Sciences, Thammasat University, Pathumtani, \\ Thailand; ${ }^{\mathrm{b}}$ Blood Bank, Thammasat University Hospital, Pathumtani, Thailand
}

\section{Keywords}

High-resolution melting curve analysis - Genotypes · Blood group antigens · Thais

\begin{abstract}
Background: High-resolution melting (HRM) analysis is an alternative method for red cell genotyping. Differences in melting curves between homozygous and heterozygous genotypes can predict phenotypes in blood group systems based on single-nucleotide polymorphisms. This study aimed to implement HRM analysis to predict additional extended blood group phenotypes in Thai donor and patient populations. Methods: Blood samples obtained from 300 unrelated Thai blood donors and 23 patients with chronic transfusions were included. HRM analysis was developed and validated in genotyping of $K E L^{*} 01$ and $K E L^{*} 02, J K^{*} 01$ and $J K^{*} 02, F Y^{*} 01, F Y^{*} 02$, and $F Y^{*} 02$ N.01,DI*01 and D $I^{*} 02, G Y P B^{*} 03$ and $G_{Y P B}^{*} 04, R H C E^{*} E$ and $R H C E^{*} e$, and DO*01 and DO*02. Then genotyping results from HRM and polymerase chain reaction with sequence-specific primer (PCR-SSP) and phenotyping results were compared. Results: The validated genotyping results in known DNA controls by HRM analysis agreed with DNA sequencing. The genotyping results among 300 donors in 15 alleles by HRM analysis were in complete concordance with those obtained by serological testing and PCR-SSP. The sensitivity and specificity of the HRM assay were both $100 \%$. Among patients, 13 had alloantibodies that possessed predicted antigen-negative phenotypes corresponding to those antibody specificities, and the highest probability of genotyped-matched donors was given to the remaining patients. Conclusions: We developed and im-
\end{abstract}

\section{karger@karger.com} www.karger.com/tmh

Karger $\frac{1}{\%}$

BOPEN ACCESS
(C) 2021 The Author(s)

Published by S. Karger AG, Basel

This is an Open Access article licensed under the Creative Common Attribution-NonCommercial-4.0 International License (CC BY-NC) (http://www.karger.com/Services/OpenAccessLicense), applicable to the online version of the article only. Usage and distribution for commercial purposes requires written permission. plemented the HRM analysis assay for red cell genotyping to predict extended blood group antigens in Thai donor and patient populations. The data from this study may help inform about and support transfusion care of Thai patients to reduce the risk of alloimmunisation.

(c) 2021 The Author(s).

Published by S. Karger AG, Basel

\section{Introduction}

More than 340 red cell antigens, classified into 43 blood group systems have been formally established by the International Society of Blood Transfusion Working Party on Red Cell Immunogenetics and Blood Group Terminology [1]. According to the standard guidelines, pretransfusion testing consisting of $\mathrm{ABO}$ grouping and $\mathrm{Rh}(\mathrm{D})$ typing, antibody screening test and crossmatching are essential for transfusion candidates to prevent incompatible blood transfusions [2, 3]. Among patients with positive antibody screening, antibody identification should be performed to determine antibody specificity and provide donor blood lacking the corresponding antigen to the patients [2-4]. In some cases, with recent transfusions, circulating red cells comprise a mixture of the patient and the donor red cells. Moreover, positive autocontrol or direct antiglobulin test results were found among patients with combined autoantibody and alloantibodies. Therefore, the antigen profile cannot be reliably determined among those patients $[2,5]$. To date, the molecular basis of blood group antigens has been assigned, and DNA analysis of extended blood group genotyping plays a supportive role to provide antigen-matched donor 
blood to the cases mentioned above, especially among chronically transfused patients [4, 6-8].

In Thailand, the allele-specific PCR or PCR sequencespecific primer (PCR-SSP) as well as multiplex PCR were applied in donor and patient populations to predict antigens in several blood group systems including Kidd $\left(J K^{*} 01\right.$ and $\left.J K^{*} 02\right)$, Duffy $\left(F Y^{*} 01, F Y^{*} 02\right.$ and $F Y^{*} 02$ N.01), Diego (DI*01 and DI*02), MNS $\left(G Y P B^{*} 03\right.$ and $\left.G Y P B^{*} 04\right)$, Kell (KEL*01 and KEL*02), Rh (RHCE*E and RHCE* ${ }^{*}$ ) and Dombrock (DO*01 and DO*02) [9-15]. Commercially available high-throughput techniques for red cell genotyping have also been implemented, but only in specialised reference laboratories due to their high cost of reagents and sophisticated equipment required [16].

Even though PCR-SSP and multiplex PCR are costeffective and straightforward, errors in interpreting results may occur during the analysis of post-PCR gel electrophoresis and manual inspection. To solve these problems, high-resolution melting (HRM) analysis has been applied to identify antigens of the Duffy, Kidd, and Diego blood group systems in a Japanese blood donor population. The predicted $\mathrm{Fy}^{\mathrm{a}}, \mathrm{Fy}^{\mathrm{b}}, \mathrm{Jk}^{\mathrm{a}}, \mathrm{Jk}^{\mathrm{b}}, \mathrm{Di}^{\mathrm{a}}$, and $\mathrm{Di}^{\mathrm{b}}$ antigens were differentiated by a change in the melting temperature $\left(\mathrm{T}_{\mathrm{m}}\right)$ of homozygote and heterozygote genotypes, and the results agreed with serological testing [17]. Other blood group allelesincluded $D O^{*} 01 / D O^{*} 02, D I^{*} 01 / D I^{*} 02$, $L U^{*} 01 / L U^{*} 02$, and $G Y P B^{*} 03 / G Y P B^{*} 04$ determined by the HRM assay, and genotyping data were in complete concordance with the PCR-SSP [18]. Moreover, the HRM assay for red cell genotyping is suitable for the demand of small-scale laboratories. This study aimed to implement the HRM analysis to predict additional extended blood group phenotypes in Thai donor and patient populations.

\section{Materials and Methods}

\section{Study Population}

EDTA-anticoagulated samples were collected from the peripheral blood of 300 unrelated healthy Thai blood donors at the Blood Bank, Thammasat University Hospital, Pathumtani, Thailand, from October 2020 to March 2021.

The study included 23 patients with chronic transfusion therapy attending the hospital's Haematology Unit. They had been transfused within the preceding 3 months. They had alloantibodies and/or autoantibody plus positive direct antiglobulin tests performed by a column agglutination test using an Ortho Vision Analyser (Ortho-Clinical Diagnostics, Raritan, NJ, USA). Patients' records were evaluated retrospectively during the study for evidence of transfusion reaction occurring in the final unit of the transfusion.

Genomic DNA from each sample was prepared using the DNeasy Blood \& Tissue Kit according to manufacturer instructions (Qiagen $\mathrm{GmbH}$, Valencia, CA, USA), then stored at $-20^{\circ} \mathrm{C}$ until genotyping.

This study was approved by the Committee on Human Rights Related to Research Involving Human Subjects, Thammasat University, Pathumtani, Thailand (COE No. 026/2563).
Controls Used in the PCR-SSP and HRM Assays

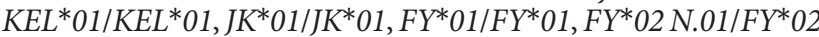
N.01, DI*01/DI*01, GYPB*03/GYPB*03, DO*01/DO*01, and RHCE*E/RHCE*E homozygote, KEL*02/KEL*02, JK*02/JK*02, $F^{*} 02 / F Y^{*} 02, D^{*} 02 / D I^{*} 02$, GYPB*04/GYPB*04, DO*02/DO*02, and $R H C E^{*} e / R H C E^{*} e$ homozygote and $K E L^{*} 01 / K E L^{*} 02, J K^{*} 01 /$ $J K^{*} 02, F^{*} 01 / F Y^{*} 02, D I^{*} 01 / D I^{*} 02, G Y P B^{*} 03 / G Y P B^{*} 04, D O^{*} 01 /$ $D O^{*} 02$, and $R H C E^{*} E / R H C E^{*} e$ heterozygote DNA controls used in the PCR-SSP and HRM assays were genotyped using standard DNA sequencing. These DNA controls have been used in related studies [9-15].

\section{Serological Antigen Typing in Donor Samples}

Antigen typing was conducted according to manufacturer instructions. All samples were phenotyped for $\mathrm{K}, \mathrm{k}, \mathrm{Jk}^{\mathrm{a}}, \mathrm{Jk}^{\mathrm{b}}, \mathrm{Fy}^{\mathrm{a}}, \mathrm{Fy}^{\mathrm{b}}$, $\mathrm{E}$, and e antigens using gel technique (Bio-Rad Laboratories AG, Cressier, Switzerland). The $\mathrm{Di}^{\mathrm{a}}, \mathrm{S}$, and $\mathrm{s}$ were typed using the conventional tube technique, using human anti- $\mathrm{Di}^{\mathrm{a}}$, anti-S, and anti-s (CE-Immunodiagnostika GmbH, Eschelbronn, Germany).

Determining Genotypes Using the PCR-SSP Assay

For the individual genotyping of the Kell $\left(K E L^{*} 01\right.$ and $\left.K E L^{*} 02\right)$, Kidd $\left(J K^{*} 01\right.$ and $\left.J K^{*} 02\right)$, Duffy $\left(F Y^{*} 01, F Y^{*} 02\right.$, and $F Y^{*} 02$ N.01), Diego (DI*01 and $\left.D I^{*} 02\right)$, MNS (GYPB*03 and GYPB*04), Dombrock $\left(D O^{*} 01\right.$ and $\left.D O^{*} 02\right)$ and $\mathrm{Rh}\left(R H C E^{*} E\right.$ and $\left.R H C E^{*} e\right)$ blood group systems, the primers and PCR conditions were identical to related reports [9-15].

Determining Genotypes by HRM Analysis Assay

PCR and HRM genotyping assays were used for genotyping all DNA samples. Each pair of forward and reverse primers Kell-F/ Kell-R, Kidd-F/Kidd-R, Duffy-F/Duffy-R, GATA-F/GATA-R, Diego-F/Diego-R, MNS-F/MNS-R, Dombrock-F/Dombrock-R, and RhCE-F/RhCE-R was designed to amplify corresponding genes (Table 1). The PCR products of $125,136,103,81,73,89,92$, and 116 bp are expected for KEL, JK, ACKR1, DI, GYPB, DO, and RHCE, respectively. A DNA typing kit (Type-it HRM PCR Kit, Qiagen GmbH, Valencia, CA, USA) was used to perform the PCRHRM assay.

In a PCR reaction mix, $10 \mu \mathrm{L}$ of $2 \times$ HRM PCR Master Mix reagent, $1 \mu \mathrm{L}$ of genomic DNA (10-50 ng/ $\mu \mathrm{L}$ concentration), and 0.7 $\mu \mathrm{L}(10 \mu \mathrm{M})$ each of forward and reverse primers were combined with water $(7.6 \mu \mathrm{L})$ to make a final volume of $20 \mu \mathrm{L}$. PCR reaction tubes were placed on a real-time PCR cycler (Rotor-Gene Q 5plex HRM, Qiagen GmbH, Valencia, CA, USA). The cycling parameters for the PCR programme consisted of initial denaturation at $95^{\circ} \mathrm{C}$ for $5 \mathrm{~min}$, followed by 40 cycles at $95^{\circ} \mathrm{C}$ for $30 \mathrm{~s}, 61^{\circ} \mathrm{C}$ for 40 $\mathrm{s}$, and $72^{\circ} \mathrm{C}$ for $30 \mathrm{~s}$. At the end of the PCR step, the temperature was gradually increased by $0.1^{\circ} \mathrm{C}$ every $2 \mathrm{~s}$ from 65 to $95^{\circ} \mathrm{C}$.

Total fluorescence and the rate of change in fluorescence were monitored and data were acquired on the green and HRM channels. Rotor-Gene Q Series Software was used to analyse the HRM data. Unknown melting profiles of DNA samples were compared with a set of determined controls on an allele-target basis. A confidence threshold of $90 \%$ was set for the HRM genotyping call.

To increase the validity and reliability of the evaluation, the technicians were blinded from the serological and PCR-SSP results. DNA sequencing was performed in case any discrepant genotyping results were obtained using the HRM and PCR-SSP assays.

\section{DNA Sequencing}

The genomic DNA of 30 randomly repeated samples was sequenced to confirm the genotyping results obtained by PCR-SSP and HRM analysis assays. The amplified fragments were sequenced 
Table 1. Description of primers used for HRM analysis assay

\begin{tabular}{|c|c|c|c|c|}
\hline Name of primer & Sequence of primer $\left(5^{\prime}-3^{\prime}\right)$ & PCR product size, bp & Gene/product & SNVs \\
\hline Kell-F & TCCTAGGTAGGCTCTGAAGAAAG & 125 & KEL & c. $578 \mathrm{C} / \mathrm{T}$ \\
\hline Kell-R & TCTCTCCTTTAAAGCTTGGAGGC & & & \\
\hline Kidd-F & TAGTCCTGAGTTCTGACCCCTC & 136 & $J K$ & c.838G/A \\
\hline Kidd-R & TGAGCGCCATGAACATTCCTC & & & \\
\hline Duffy-F & GTATGGAATTCTTCCTATGGTGTGA & 103 & ACKR1 & c. $125 \mathrm{G} / \mathrm{A}$ \\
\hline Duffy-R & CATCCAGCAGGTTACAGGAGT & & & \\
\hline GATA-F & CCTGCCCAGAACCTGATGG & 81 & ACKR1 & c.-69T/C \\
\hline GATA-R & CAGACAGAAGGGCTGGGAC & & & \\
\hline Diego-F & AGCGGCACAGTGAGGATGAG & 73 & $D I$ & c. $2561 \mathrm{C} / \mathrm{T}$ \\
\hline Diego-R & CAGTGCTGTGGGTGGTGA & & & \\
\hline MNS-F & ACCTGGTACAGTGAAACGATG & 89 & GYPB & c. $143 \mathrm{C} / \mathrm{T}$ \\
\hline MNS-R & TGCACATGTCTTTCTTATTTGGACT & & & \\
\hline Dombrock-F & GCTCAGGTTCCCAGTTGACC & 92 & $D O$ & c.793A/G \\
\hline Dombrock-R & TGATCCCTCCCTATGAGCTGT & & & \\
\hline $\mathrm{RhCE}-\mathrm{F}$ & TCACCACACTGACTGCTAGA & 116 & RHCE & c.676G/C \\
\hline RhCE-R & CGCCCTCTTCTTGTGGATGT & & & \\
\hline
\end{tabular}

SNVs, single-nucleotide variations.

based on the method described by Sanger and Coulson [19], which was similar to PCR mixtures and conditions in each gene target amplification. Sequences of primer pairs of each gene target ( $\mathrm{Ta}$ ble 1) and PCR condition were identical to "Determining genotypes by HRM analysis assay."

For each PCR reaction, $2 \mu \mathrm{L}$ of genomic DNA $(50 \mathrm{ng} / \mu \mathrm{L})$ was amplified in a total volume of $50 \mu \mathrm{L}$ using $1 \mu \mathrm{L}$ of $10 \mu \mathrm{M}$ forward primers and $1 \mu \mathrm{L}$ of $10 \mu \mathrm{M}$ reverse primers for each reaction. PCR was performed with $25 \mu \mathrm{L}$ of $2 \times$ PCR reaction mixture (Phusion High-Fidelity PCR Master Mix; New England Biolabs, Ipswich, MA, USA) and $21 \mu \mathrm{L}$ of sterile distilled water in a T100 Thermal cycler (Bio-Rad Laboratories Inc., Hercules, CA, USA).

PCR products were electrophoresed at $100 \mathrm{~V}$ with a $1.5 \%$ agarose gel containing 100,00× fluorescent DNA gel stain (SYBR Safe DNA gel stain, Invitrogen, Paisley, UK) using a $1 \times$ TBE buffer. Products were visualised under a blue-light transilluminator. After that, amplicons were purified using a gel extraction kit (QIAquick Gel Extraction Kit, Qiagen GmbH, Valencia, CA, USA). Using these PCR primers, eluted fragments were then sequenced (U2Bio DNA Sequencing Services, Bangkok, Thailand).

Statistical Analysis

Considering the extended blood group genotypes performed by the HRM analysis, the results were analysed and compared with the standard serological tests (conventional tube test and column agglutination test) and PCR-SSP results. The sensitivity and specificity of the HRM analysis assay were calculated according to serological tests and PCR-SSP (used for the Dombrock blood group system) as the reference standard in this study.

\section{Results}

The Individual Phenotypes of Kell, Kidd, Duffy, Diego, MNS, and Rh Blood Group Systems

Three hundred blood samples from unrelated Thai blood donors were tested using serological blood group antigen typing (Table 2). For the Kell system, all donors were $\mathrm{K}-\mathrm{k}+$ phenotypes. Three phenotypes of the Kidd system were observed including $\mathrm{Jk}(\mathrm{a}+\mathrm{b}+), 134 / 300 ; \mathrm{Jk}(\mathrm{a}-\mathrm{b}+)$, $84 / 300$, and $\mathrm{Jk}(\mathrm{a}+\mathrm{b}-), 82 / 300$, respectively. Regarding the Duffy system, Fy $(\mathrm{a}+\mathrm{b}-)$ was frequently observed (258/300), followed by $\mathrm{Fy}(\mathrm{a}+\mathrm{b}+), 41 / 300$, and $\mathrm{Fy}(\mathrm{a}-\mathrm{b}+), 1 / 300$, and $\mathrm{Fy}(\mathrm{a}-\mathrm{b}-)$ was not found. Only 2 phenotypes were found in the Diego system including $\mathrm{Di}(\mathrm{a}-\mathrm{b}+), 185 / 300$, and $\operatorname{Di}(\mathrm{a}+\mathrm{b}+), 15 / 300$. For the $\mathrm{S}$ and $\mathrm{s}$ phenotypes in the MNS system, the most common phenotype was $\mathrm{S}-\mathrm{s}+, 262 / 300$, followed by $\mathrm{S}+\mathrm{s}+, 37 / 300$, and $\mathrm{S}+\mathrm{s}^{-}, 1 / 300$, in rank. Additionally, the $\mathrm{E}-\mathrm{e}+$ phenotype in the $\mathrm{Rh}$ system was the most frequent (199/300), followed by E+e+ (92/300), and $\mathrm{E}+\mathrm{e}-$ phenotypes (9/300), respectively.

The Individual Genotypes of Kell, Kidd, Duffy, Diego, MNS, Rh, and Dombrock Blood Group Systems Were Determined Using PCR-SSP

The frequencies of $K E L^{*} 01$ and $K E L^{*} 02, J K^{*} 01$ and $J K^{*} 02, F Y^{*} 01, F Y^{*} 02$, and $F Y^{*} 02$ N.01, DI*01 and DI*02, $G Y P B^{*} 03$ and $G Y P B^{*} 04$, and $R H C E^{*} E$ and $R H C E^{*} e$ among 300 samples determined by PCR-SSP are shown in Table 2. The predicted phenotypes of Kell, Kidd, Duffy, Diego, MNS, and Rh blood group systems obtained from individual testing by PCR-SSP in all samples were identical to those mentioned above determined using standard serological tests. For the Dombrock blood group system, only PCR-SSP was used to determine genotypes and predicted phenotypes due to the unavailability of commercial antiserum. The $D O^{*} B / D O^{*} B$ genotype was the most common (223/300), followed by $D O^{*} A / D O^{*} B(70 / 300)$, and $D O^{*} A / D O^{*} A(7 / 300)$, in rank (Table 2). 
Table 2. Concordance between serological phenotypes and genotypes of Kell, Kidd, Duffy, Diego, MNS, Rh, and Dombrock blood group systems in 300 donor samples

\begin{tabular}{llll}
\hline Phenotype & Genotype & & \multirow{2}{*}{ Numbers } \\
\cline { 2 - 3 } & PCR-SSP & HRM & 300 \\
\hline $\mathrm{K}-\mathrm{k}+$ & $K E L^{*} 02 / K E L^{*} 02$ & $K E L^{*} 02 / K E L^{*} 02$ & 82 \\
$\mathrm{Jk}(\mathrm{a}+\mathrm{b}-)$ & $J K^{*} 01 / J K^{*} 01$ & $J K^{*} 01 / J K^{*} 01$ & 134 \\
$\mathrm{Jk}(\mathrm{a}+\mathrm{b}+)$ & $J K^{*} 01 / J K^{*} 02$ & $J K^{*} 01 / J K^{*} 02$ & 84 \\
$\mathrm{Jk}(\mathrm{a}-\mathrm{b}+)$ & $J K^{*} 02 / J K^{*} 02$ & $J K^{*} 02 / J K^{*} 02$ & 258 \\
$\mathrm{Fy}(\mathrm{a}+\mathrm{b}-)$ & $F Y^{*} 01 / F Y^{*} 01$ & $F Y^{*} 01 / F Y^{*} 01$ & 41 \\
$\mathrm{Fy}(\mathrm{a}+\mathrm{b}+)$ & $F Y^{*} 01 / F Y^{*} 02$ & $F Y^{*} 01 / F Y^{*} 02$ & 1 \\
$\mathrm{Fy}(\mathrm{a}-\mathrm{b}+)$ & $F Y^{*} 02 / F Y^{*} 02$ & $F Y^{*} 02 / F Y^{*} 02$ & 15 \\
$\mathrm{Di}(\mathrm{a}+\mathrm{b}+)$ & $D I^{*} 01 / D I^{*} 02$ & $D I^{*} 01 / D I^{*} 02$ & 185 \\
$\mathrm{Di}(\mathrm{a}-\mathrm{b}+)$ & $D I^{*} 02 / D I^{*} 02$ & $D I^{*} 02 / D I^{*} 02$ & 262 \\
$\mathrm{~S}-\mathrm{s}+$ & $G Y P B^{*} 04 / G Y P B^{*} 04$ & $G Y P B^{*} 04 / G Y P B^{*} 04$ & 37 \\
$\mathrm{~S}+\mathrm{s}+$ & $G Y P B^{*} 03 / G Y P B^{*} 04$ & $G Y P B^{*} 03 / G Y P B^{*} 04$ & 1 \\
$\mathrm{~S}+\mathrm{s}-$ & $G Y P B^{*} 03 / G Y P B^{*} 03$ & $G Y P B^{*} 03 / G Y P B^{*} 03$ & 199 \\
$\mathrm{E}-\mathrm{e}+$ & $R H C E^{*} e / R H C E^{*} e$ & $R H C E^{*} e / R H C E^{*} e$ & 92 \\
$\mathrm{E}+\mathrm{e}+$ & $R H C E^{*} E / R H C E^{*} e$ & $R H C E^{*} E / R H C E^{*} e$ & 9 \\
$\mathrm{E}+\mathrm{e}-$ & $R H C E^{*} E / R H C E^{*} E$ & $R H C E^{*} E / R H C E^{*} E$ & 223 \\
$\mathrm{NA}$ & $D O^{*} 02 / D O^{*} 02$ & $D O^{*} 02 / D O^{*} 02$ & 70 \\
$\mathrm{NA}$ & $D O^{*} 01 / D O^{*} 02$ & $D O^{*} 01 / D O^{*} 02$ & 7 \\
$\mathrm{NA}$ & $D O^{*} 01 / D O^{*} 01$ & $D O^{*} 01 / D O^{*} 01$ & \\
\hline
\end{tabular}

NA, not applicable.

Validating HRM Analysis to Identify Individual

Genotyping of Kell, Kidd, Duffy, Diego, MNS,

Dombrock, and Rh Blood Group Systems

Known DNA controls confirmed by standard DNA sequencing, $K E L^{*} 01 / K E L^{*} 01, J K^{*} 01 / J K^{*} 01, F Y^{*} 01 / F Y^{*} 01$, FY*02 N.01/FY*02 N.01, DI*01/DI*01, GYPB*03/ $G Y P B^{*} 03, D O^{*} 01 / D O^{*} 01$, and $R H C E^{*} E / R H C E^{*} E$ homozygote, $K E L^{*} 02 / K E L^{*} 02, J K^{*} 02 / J K^{*} 02, F Y^{*} 02 / F Y^{*} 02$, $D I^{*} 02 / D I^{*} 02, G Y P B^{*} 04 / G Y P B^{*} 04, D O^{*} 02 / D O^{*} 02$, and RHCE* $/ R H C E^{*} e$ homozygote, and KEL*01/KEL*02, $J K^{*} 01 / J K^{*} 02, \quad F Y^{*} 01 / F Y^{*} 02, D^{*} 01 / D I^{*} 02, \quad G Y P B^{*} 03 /$ $G Y P B^{*} 04, D O^{*} 01 / D O^{*} 02$, and $R H C E^{*} E / R H C E^{*} e$ heterozygote were used to validate the HRM analysis to identify those genotypes. The HRM curve of each genotype in the corresponding blood group system was differentiated, as shown in Figure 1.

HRM Analysis for Genotyping KEL*01 and KEL*02,

$J K^{*} 01$ and $J K^{*} 02, F Y^{*} 01$ and $F Y^{*} 02, D I^{*} 01$ and

$D I^{*} 02, G Y P B^{*} 03$ and $G Y P B^{*} 04, D O^{*} 01$ and $D O^{*} 02$,

and $\mathrm{RHCE}^{*} \mathrm{E}$ and $\mathrm{RHCE}^{*}$ e Alleles

DNA controls of $K E L^{*} 01 / K E L^{*} 01, K E L^{*} 01 / K E L^{*} 02$, $K E L^{*} 02 / K E L^{*} 02, \quad J K^{*} 01 / J K^{*} 01, \quad J K^{*} 01 / J K^{*} 02, \quad J K^{*} 02 /$ $J K^{*} 02, F Y^{*} 01 / F Y^{*} 01, F Y^{*} 01 / F Y^{*} 02, F Y^{*} 02 / F Y^{*} 02, D I^{*} 01 /$ $D I^{*} 01, D I^{*} 01 / D I^{*} 02, D I^{*} 02 / D I^{*} 02, G^{*} P B^{*} 03 / G Y P B^{*} 03$, $G Y P B^{*} 03 / G Y P B^{*} 04, G Y P B^{*} 04 / G Y P B^{*} 04, D O^{*} 01 / D O^{*} 01$, DO*01/DO*02, DO*02/DO*02, RHCE*E/RHCE*E, $R H C E^{*} E / R H C E^{*} e$, and $R H C E^{*} e / R H C E^{*} e$ were amplified and analysed using the HRM assay, while $K E L^{*} 01$ and $K E L^{*} 02, J K^{*} 01$ and $J K^{*} 02, F Y^{*} 01$ and $F Y^{*} 02, D I^{*} 01$ and $D I^{*} 02, G Y P B^{*} 03$ and $G Y P B^{*} 04, D O^{*} 01$ and $D O^{*} 02$, $R H C E^{*} E$ and $R H C E^{*} e$ alleles were genotyped using HRM curves. Representative normalised HRM curves were of 3 types: the red curve representing the homozygous $K E L^{*} 01 / K E L^{*} 01, \quad J K^{*} 01 / J K^{*} 01, \quad F Y^{*} 01 / F Y^{*} 01, \quad D I^{*} 01 /$ $D I^{*} 01, G Y P B^{*} 03 / G Y P B^{*} 03, D O^{*} 01 / D O^{*} 01$, and $R H C E^{*} E /$ $R H C E^{*} E$ genotypes, the purple curve representing the heterozygous $K E L^{*} 01 / K E L^{*} 02, J K^{*} 01 / J K^{*} 02, F Y^{*} 01 / F Y^{*} 02$, $D I^{*} 01 / D I^{*} 02, G^{*} B^{*} 03 / G Y P B^{*} 04, D O^{*} 01 / D O^{*} 02$, and $R H C E^{*} E / R H C E^{*} e$ genotypes, and the green curve representing the homozygous $K E L^{*} 02 / K E L^{*} 02, J K^{*} 02 / J K^{*} 02$, $F Y^{*} 02 / F Y^{*} 02, D I^{*} 02 / D I^{*} 02, G Y P B^{*} 04 / G Y P B^{*} 04, D O^{*} 02 /$ $D O^{*} 02$, and $R H C E^{*} e / R H C E^{*} e$ genotypes. HRM curves showed a separation in those 3 genotypes at $\mathrm{T}_{\mathrm{m}}$ ranging from 79.5 to $80.1^{\circ} \mathrm{C}, 82.3-82.6^{\circ} \mathrm{C}, 81.0-81.6^{\circ} \mathrm{C}, 84.8-$ $85.5^{\circ} \mathrm{C}, 75.8-76.3^{\circ} \mathrm{C}, 78.5-78.9^{\circ} \mathrm{C}$, and $81.0-81.2^{\circ} \mathrm{C}$ for Kell, Kidd, Duffy, Diego, MNS, Dombrock, and Rh genotyping, respectively (Fig. 1A-C and E-H).

To identify $F Y^{*} 02 \mathrm{~N} .01$ alleles, DNA controls of $F Y^{*} 02$ N.01/FY*02 N.01 and wild-type $F Y^{*} 01$ and $F Y^{*} 02$ GATA $\left(F Y^{*} 01 / F Y^{*} 01, F Y^{*} 01 / F Y^{*} 02\right.$, and $\left.F Y^{*} 02 / F Y^{*} 02\right)$ genotypes were amplified and analysed using the HRM assay. Representative normalised HRM curves were of 4 types: the yellow curve representing the homozygous $F Y^{*} 02$ N.01/FY*02 N.01 genotypes, and the red, purple, and green curves representing $F Y^{*} 01 / F Y^{*} 01, F Y^{*} 01 / F Y^{*} 02$, 
A) $K E L * 01$ and $K E L * 02$

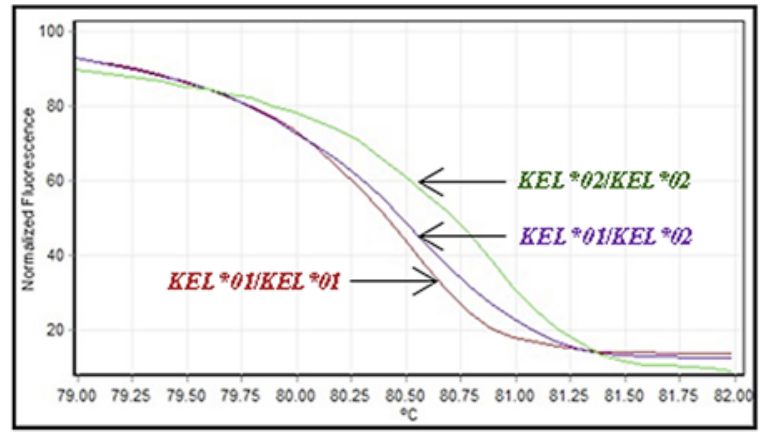

C) $F Y^{*} 01$ and $F Y^{*} 02$

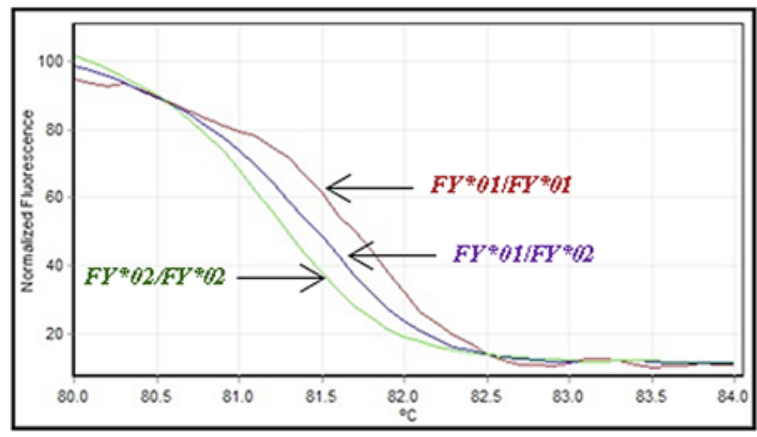

E) $D I^{*} 01$ and $D I^{*} 02$

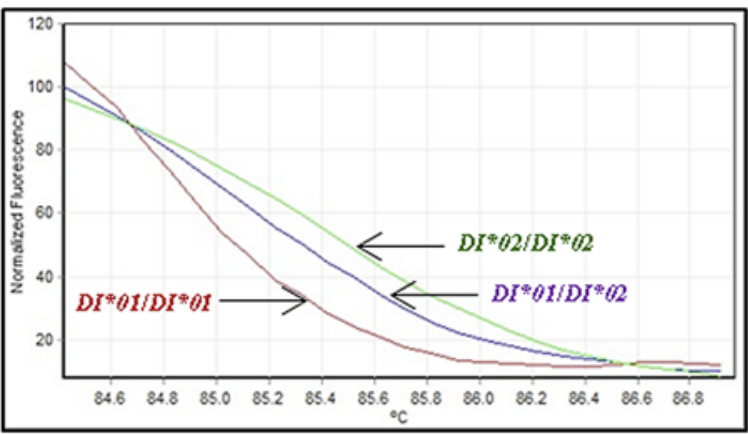

\section{G) $R H C E^{*} E$ and $R H C E^{*} e$}

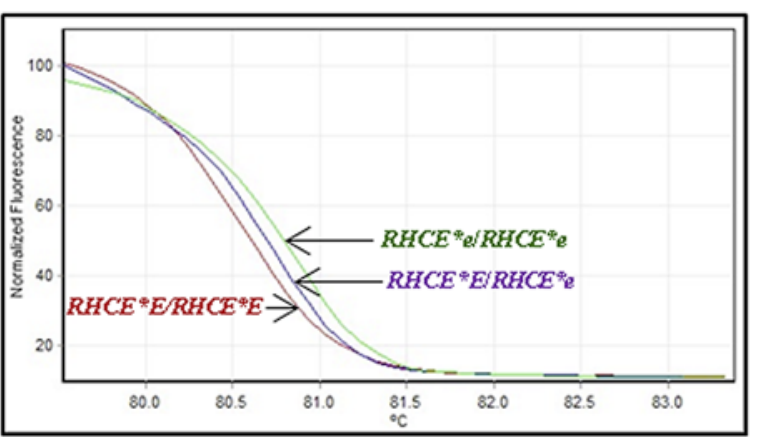

B) $J K^{*} 01$ and $J K^{*} 02$

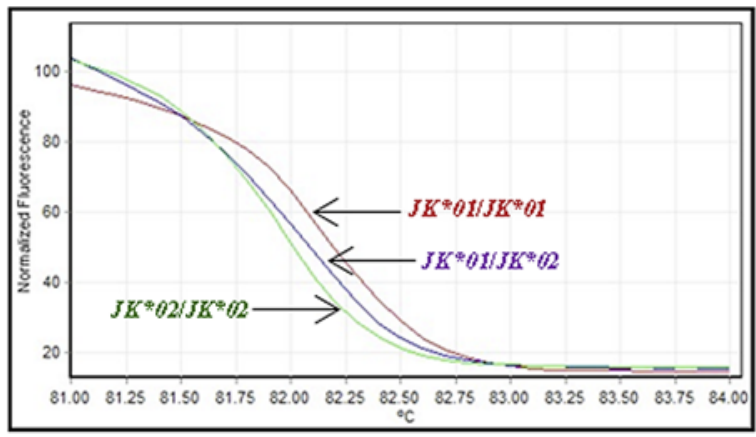

D) Wild-type and mutant $F Y^{*} 02$ GATA

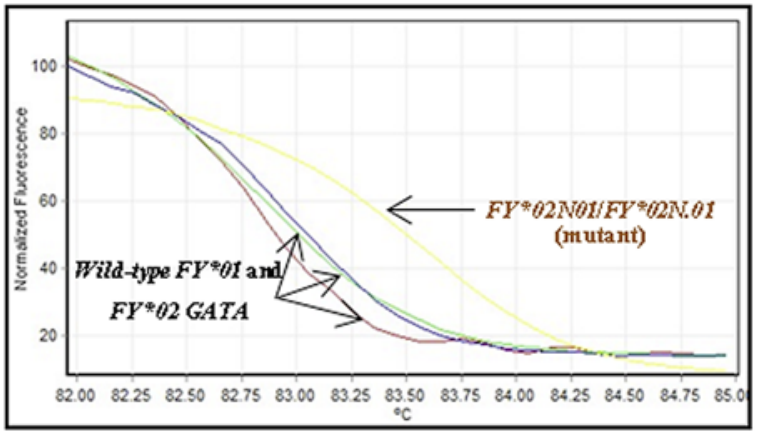

F) $G Y P B * 03$ and $G Y P B * 04$

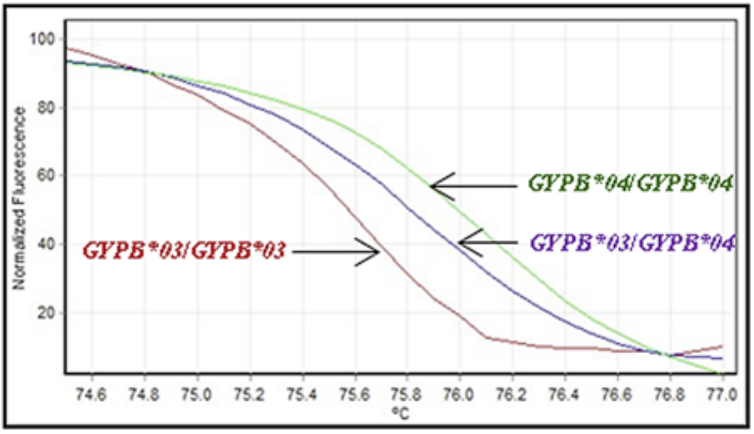

H) $D O * 01$ and $D O * 02$

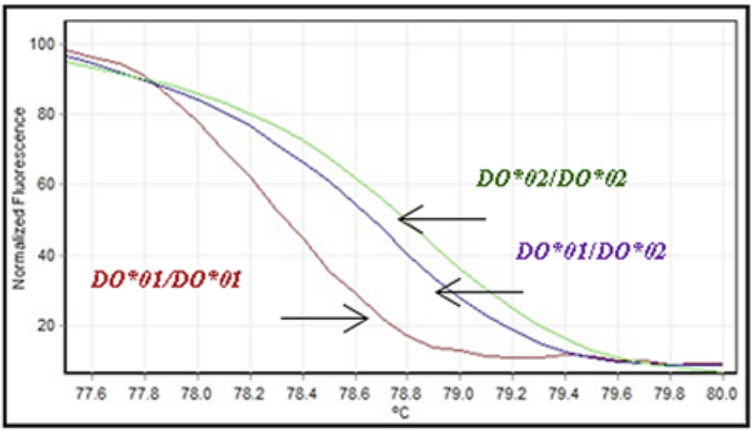

Fig. 1. HRM analysis of Kell, Kidd, Duffy, Diego, MNS, Rh, and Dombrock genotypes. A $K E L^{*} 01$ and $K E L^{*} 02$. B $J K^{*} 01$ and $J K^{*} 02$. C $F Y^{*} 01$ and $F Y^{*} 02$. D Wild-type and mutant $F Y^{*} 02$. E DI*01 and DI*02. F GYPB*03 and GYPB*04. G RHCE*E and RHCE*e. H DO*01 and DO*02. 
Table 3. Red cell antibody frequencies and specificities found among 23 patients

\begin{tabular}{|c|c|c|}
\hline Antibody specificity & Number & Percent \\
\hline Single antibody & 13 & 56.52 \\
\hline Anti-Mia & 5 & 21.74 \\
\hline Anti-Dia & 2 & 8.70 \\
\hline Anti-E & 2 & 8.70 \\
\hline Anti-S & 2 & 8.70 \\
\hline Anti-Jk ${ }^{b}$ & 1 & 4.34 \\
\hline Anti-P1 & 1 & 4.34 \\
\hline Multiple antibodies & 6 & 26.10 \\
\hline Anti-E + -c & 1 & 4.34 \\
\hline Anti-E + -S & 1 & 4.34 \\
\hline Anti-E $+-c+-M i^{a}$ & 2 & 8.70 \\
\hline Anti-E $+-c+-J k^{a}$ & 1 & 4.34 \\
\hline Anti-Mia $+-D i^{a}+$ unidentified & 1 & 4.34 \\
\hline Unidentified specificity & 3 & 13.04 \\
\hline Autoantibody & 1 & 4.34 \\
\hline Total & 23 & 100.00 \\
\hline
\end{tabular}

and $F Y^{*} 02 / F Y^{*} 02$, respectively. HRM curves of those genotypes were separated at $\mathrm{T}_{\mathrm{m}}$ ranging from 83.0 to $83.6^{\circ} \mathrm{C}$ (Fig. 1D).

The developed HRM assay was implemented in 300 donor samples to predict phenotypes of Kell, Kidd, Duffy, Diego, MNS, and Rh blood group systems. The results obtained agreed with those obtained for serological phenotypes and genotypes by PCR-SSP. The sensitivity and specificity of the HRM assay were $100 \%$ and $100 \%$, respectively (Table 2).

\section{Implementing the HRM Assay to Predict Extended}

Blood Group Phenotypes among Patients with Chronic Transfusion Therapy

Of the 23 patients with chronic transfusion therapy, 22 had alloantibodies, and 1 had only an autoantibody (Table 3). Regarding the antibody specificities found among 22 patients, $13(56.52 \%)$ patients had a single antibody, 6 (26.10\%) had multiple antibodies ( 2 or 3 specificities), and inconclusive results reported as unidentified specificity were demonstrated among 3 (13.04\%) patients. Anti-Mia ${ }^{\mathrm{a}}$, anti-E, anti-c, and anti- $\mathrm{Di}^{\mathrm{a}}$ were commonly found among those patients. All patient samples were genotyped using the HRM assay and PCR-SSP. The results of predicted blood group phenotypes obtained by the HRM assay were $100 \%$ in accordance with the PCRSSP. Moreover, the results of predicted phenotypes correlated with antibody specificities detected in each patient. The corresponding antigen-negative matched donor blood units were primarily given to patients with antibody specificity. The highest probability of genotypematched donors was given to patients with undetermined specificity. Compatible crossmatch units were transfused to all patients and without any evidence of transfusion reactions occurring after the transfusions.

\section{Discussion}

HRM analysis is an ingenious technique for genotyping based on PCR melting (dissociation) curve techniques following rapid-cycle PCR of small amplicons, suitable for single-nucleotide polymorphisms. Samples are also distinguished by their sequence length, GC content, and strand complementarities. Differences can be detected using specific DNA dyes, high-end instrumentation, and software analysis. Heterozygous genotypes can be easily determined by alterations in the melting curve shape, and various homozygote genotypes are identified by a change in $\mathrm{T}_{\mathrm{m}}$. HRM analysis has been successfully applied to study possible single-nucleotide polymorphism base change in haematological disorders including factor $\mathrm{V}$ Leiden c.1691G $>$ A, prothrombin c.20210G $>$ A, methylenetetrahydrofolate reductase c.1298A $>$ C, hemochromatosis c.187C $>\mathrm{G}$ and $\beta$-globin (haemoglobin S) c.17A $>\mathrm{T}$ [20]. Additionally, this HRM assay was beneficial in confirming human leucocyte antigen genotype identity between unrelated donors and patients before haematopoietic stem cell transplantation [21]. For red cell genotyping, the predicted phenotypes of Duffy, Kidd, Diego, Dombrock, Lutheran, and MNS blood group systems determined by the HRM assay provided accurate and reliable typing results compared with serological tests and PCR-SSP $[17,18]$.

This study validated the developed HRM assay using known genotypes by DNA sequencing and applied it to predict extended blood group phenotypes in Thai donor and patient populations. The genotyping results obtained from the HRM assay were compared with typing results by serological tests and PCR-SSP. The overall typing results between molecular tests (HRM and PCR-SSP) and serological tests showed $100 \%$ concordance for each of 12 antigens: $\mathrm{K}, \mathrm{k}, \mathrm{Jk}^{\mathrm{a}}, \mathrm{Jk}^{\mathrm{b}}, \mathrm{Fy}^{\mathrm{a}}, \mathrm{Fy}^{\mathrm{b}}, \mathrm{Di}^{\mathrm{a}}, \mathrm{Di}^{\mathrm{b}}, \mathrm{S}, \mathrm{s}, \mathrm{E}$, and e antigens. Even though the $K E L^{*} 01$ allele frequencies in Thai donor populations and the probability of finding anti- $\mathrm{K}$ in Thai patients is lower than those in Caucasian populations [13, 22], 1 Thai patient with anti- $\mathrm{K}$ was reported in a recent study [23]. Hence, developing the HRM assay including not only red cell antigens frequently associated with alloantibody productions in Thai populations [22-24] $]_{2}$ but also antigens with high immunogenicity is recommended.

Patients with undetermined antibody specificity may result from using reagent red cells with only limited information of their antigens. A recent study of $D O^{*} A$ and $D O^{*} B$ allele detections from Thai blood donors revealed that anti-Do ${ }^{a}$ could have a greater alloimmunisation 
chance of producing anti-Do ${ }^{\mathrm{b}}$ [15]. At present, no information on those antigens has been included in the screening and panel cells provided by the National Blood Centre, Thai Red Cross Society. Therefore, data on the prevalence of antibodies against both antigens have remained unreported. In addition to source limitations of specific anti$\mathrm{Do}^{\mathrm{a}}$ and anti-Do ${ }^{\mathrm{b}}$, genotyping using molecular techniques would be helpful to provide information on those antigens in donor and patient populations [25]. The HRM assay in this study could provide accurate and reliable genotyping results to predict DO phenotypes compared with PCRSSP. To determine the predicted Fy $(\mathrm{a}-\mathrm{b}-)$ phenotype, the DNA controls of $\mathrm{FY}^{*} 02 \mathrm{~N} .01$ were used. The Duffy promoter variant c. $-67 \mathrm{~T}>\mathrm{C}$ is associated with both $F Y^{*} 01$ N.01 and $F Y^{*} 02$ N.01; hence, the developed HRM assay would be able to define $F Y^{*} 01$ N.01 alleles.

Of the 23 patients with chronic transfusion therapy, 13 patients had alloantibodies consisting of anti-E, anti-c, anti- $\mathrm{Di}^{\mathrm{a}}$, anti-S, anti-Jk $\mathrm{k}^{\mathrm{a}}$, and anti-Jk $\mathrm{k}^{\mathrm{b}}$ that possessed predicted antigen-negative phenotypes corresponding to those antibody specificities. Genotyping by the HRM assay provides safer blood transfusion in this patient group presenting limitations in standard serological typing. For the remaining patients, the highest probability of genotype-matched donors would be beneficial in preventing subsequent alloimmunisations. In addition, the developed HRM assay could not be used to confirm antibody specificity in 5 patients with anti- $\mathrm{Mi}^{\mathrm{a}}$ and 1 patient with anti-P1. Further development of the HRM assay in these antigens is recommended.

Based on the results, the HRM assay showed a perfect test that would exhibit $100 \%$ sensitivity and $100 \%$ specificity to predict those 14 red cell antigens. The superiority of the HRM analysis assay to implement in small-scale laboratories is that genotyping results could be obtained within $2 \mathrm{~h}$, and postanalytic gel electrophoresis is not required $[17,18]$. Generally, genotype results obtained by the HRM analysis assay were assigned by comparing sample curves with control curves. In each batch testing, DNA controls of known homozygous and heterozygous genotypes of each blood group system must be included in each run.

In conclusion, we developed and implemented the HRM analysis assay for red cell genotyping to predict extended blood group antigens in Thai donor and patient populations. The data from this study may help inform and support transfusion care of Thai patients to reduce the risk of alloimmunisation.

\section{Statement of Ethics}

This study protocol was approved by the Committee on $\mathrm{Hu}$ man Rights Related to Research Involving Human Subjects, Thammasat University, Pathumtani, Thailand, and written consent was provided by each participant.

\section{Conflict of Interest Statement}

All authors declare no conflict of interests.

\section{Funding Sources}

The research presented in this article was financed exclusively by the National Research Council of Thailand, Bangkok, Thailand. No external funding or donations were provided for this research.

\section{Author Contributions}

O.N. and K.I.: substantial contributions to study conception and design, acquisition of data, analysis and interpretation of data, assistance with compiling of the results, drafting of this paper and critical revision of important intellectual content. S.C.: selection and collection of blood donors and patients for serological and molecular testing. All of the authors approved the final version of this paper for publication.

\section{Data Availability Statement}

All data generated and analysed during this study are included in this article. Further enquiries can be directed to the corresponding author.

\section{References}

1 https: //www.isbtweb.org/working-parties/ red-cell-immunogenetics-and-blood-groupterminology [cited 2021 May 29].

2 Fung MK, Eder AF, Spitalnik SL, Westhoff CM, editors. Technical manual. 19th ed. Bethesda: AABB; 2017.

3 American Association of Blood Banks; Standards Program Committee. Standard for blood banks and transfusion practice. 31 st ed. Bethesda: AABB; 2018.

4 Daniels G. Human blood groups. 3rd ed. Malden: Blackwell Science; 2013.
5 Hamilton JR. Common and frequently encountered antibodies. Transfus Apher Sci. 2009;40:189-94.

6 Ribeiro KR, Guarnieri MH, da Costa DC, Costa FF, Pellegrino J Jr, Castilho L. DNA array analysis for red blood cell antigens facilitates the transfusion support with antigenmatched blood in patients with sickle cell disease. Vox Sang. 2009;97:147-52.

7 Guelsin GA, Sell AM, Castilho L, Masaki VL, Melo FC, Hashimoto MN, et al. Benefits of blood group genotyping in multi-transfused patients from the south of Brazil. J Clin Lab Anal. 2010;24:311-6.
8 Reid ME, Lomas-Francis C, Olsson ML. Blood group antigen factsbook. 3rd ed. London: Academic Press; 2012.

9 Intharanut K, Grams R, Bejrachandra S, Sriwanitchrak P, Nathalang O. Improved allelespecific PCR technique for Kidd blood group genotyping. J Clin Lab Anal. 2013;27:53-8.

10 Nathalang O, Intharanut K, Siriphanthong K, Nathalang S, Kupatawintu P. Duffy blood group genotyping in Thai blood donors. Ann Lab Med. 2015;35:618-23. 
11 Nathalang O, Panichrum P, Intharanut K, Thattanon P, Nathalang S. Distribution of $\mathrm{DI}^{*} \mathrm{~A}$ and $\mathrm{DI} \mathrm{B}$ allele frequencies and comparisons among central Thai and other populations. PLoS One. 2016;11:e0165134.

12 Nathalang O, Ang RM, Kurin B, Limprasert S, Mitundee S, Leetrakool N, et al. Predicted S and $s$ phenotypes from genotyping results among Thai populations to prevent transfusion-induced alloimmunization risks. Transfus Apher Sci. 2018;57:582-6.

13 Intharanut K, Khantisitthiporn O, Kupatawintu P, Leetrakool N, Mitundee S, Nathalang O. Establishment of KEL*01 and $\mathrm{KEL}^{*} 02$ genotyping to recruit uncommon, Kell-positive, reagent red cells among Thai blood donors. Clin Lab. 2019;65:1913-8.

14 Intharanut K, Bejrachandra S, Nathalang S, Leetrakool N, Nathalang O. Red cell genotyping by multiplex PCR identifies antigenmatched blood units for transfusion-dependent Thai patients. Transfus Med Hemother. 2017;44:358-64.
15 Wangmo T, Intharanut K, Leetrakool N, Mitundee S, Bejrachandra S, Nathalang O. Development of $\mathrm{DO}^{*} \mathrm{~A}$ and $\mathrm{DO} * \mathrm{~B}$ allele detections to predict transfusion-induced alloimmunization risks in Thai populations. Clin Lab. 2021;67:2225-31.

16 Nathalang O. Red cell genotyping in Thailand: trends for blood transfusion in Asian populations. VOXS. 2020;15(3):310-4

17 Tanaka M, Takahahi J, Hirayama F, Tani Y. High-resolution melting analysis for genotyping Duffy, Kidd and Diego blood group antigens. Leg Med (Tokyo). 2011;13:1-6.

18 Gong T, Hong Y, Wang N, Fu X, Zhou C. Validation of a blood group genotyping method based on high-resolution melting curve analysis. Immunohematology. 2014;30:161-5.

19 Sanger F, Coulson AR. A rapid method for determining sequences in DNA by primed synthesis with DNA polymerase. J Mol Biol. 1975;94:441-8.

20 Liew M, Pryor R, Palais R, Meadows C, Erali M, Lyon E, et al. Genotyping of single-nucleotide polymorphisms by high-resolution melting of small amplicons. Clin Chem. 2004; 50:1156-64
21 Zhou L, Vandersteen J, Wang L, Fuller T, Taylor M, Palais B, et al. High-resolution DNA melting curve analysis to establish HLA genotypic identity. Tissue Antigens. 2004;64:15664.

22 Kupatawintu P, Emthip M, Sungnoon D, Ovataga $\mathrm{P}$, Manakul V, Limtamaporn $\mathrm{S}$, et al. [Unexpected antibodies of patients, blood samples sent for testing at NBC.] J Hematol Transfus Med. 2010;20:255-62. Thai.

23 Chidtrakoon S, Jeumjanya N, Intharanut K, Nathalang O. Analysis of pretransfusion testing events occurring in patients at Thammasat University Hospital. J Hematol Transfus Med. 2020;30:345-51

24 Chandanayingyong D, Sasaki TT, Greenwalt TJ. Blood groups of the Thais. Transfusion. 1967;7:269-76.

25 Scharberg E, Rink G, Portegys J, Rothenberger S, Gillhuber N, Richter E, et al. The impact of using genotyped reagent red blood cells in antibody identification. Transfus $\mathrm{Med} \mathrm{He}$ mother. 2018;45:218-24. 